\title{
Intelligence Optimization in the Golden Age by Stimulating the Right- Brain in Mojokrapak Village, Tembelang District, Jombang Regency
}

\author{
Optimalisasi Kecerdasan Masa Keemasan dengan Merangsang Otak Kanan di Desa \\ Mojokrapak, Kecamatan Tembelang, Kabupaten Jombang
}

\author{
Rini Hayu Lestari \\ STIKes Pemkab Jombang \\ Mudhawaroh \\ STIKes Pemkab Jombang \\ Mamik Ratnawati \\ STIKes Pemkab Jombang \\ mamik.perawat@gmail.com
}

\begin{abstract}
The golden period is an extremely critical period or moment in the children's life cycle. The golden period on children is an important and critical period where children's brain and intelligence developing rapidly. The golden period for children lasted during the age of 0-3 years. The purpose of this research is to optimize the golden age period for toddlers. One of the activities is providing information and knowledge about how to optimize children's intelligence in the golden age era by stimulating the right brain. The result of this study is to create a highquality generation by preparing the mothers who can stimulate and optimize the development of children during the golden age period so that toddlers can achieve optimal development during the age of 0-3 years old.

Keywords: golden age period, optimization of children's intelligence

Abstrak

Masa emas merupakan masa atau momen yang sangat kritis dalam siklus hidup anak. Masa emas pada anak merupakan masa penting dan kritis di mana otak dan kecerdasan anak berkembang pesat. Masa emas bagi anak-anak berlangsung pada usia 0-3 tahun. Tujuan dari penelitian ini adalah untuk mengoptimalkan masa golden age pada balita. Salah satu kegiatannya adalah memberikan informasi dan pengetahuan tentang bagaimana mengoptimalkan kecerdasan anak di era golden age dengan cara merangsang otak kanan. Hasil dari penelitian ini adalah terciptanya generasi yang berkualitas dengan mempersiapkan para ibu yang dapat memacu dan mengoptimalkan tumbuh kembang anak pada masa golden age sehingga balita dapat mencapai perkembangan yang optimal pada usia 0-3 tahun.

Kata kunci: masa keemasan, optimalisasi kecerdasan anak
\end{abstract}

\section{PRELIMINARY}

Children development from age 0-3 is a critical moment or widely known with the term of golden age or golden moment. Around $80 \%$ of human's brain development happened during the golden age period. The development of insufficient cells number in this period will lead to a permanent shortage of cells. This could affect the children's life and future. This period is also seen as a period of all or nothing. It is the time where children can grow and develop according to their potential or nothing at all. In this period, a development of brain, psychological, social, and physical will happen. Due to the criticality of this period, parents needs to pay more attention to golden age period.

The golden age period is a critical or very important period in a cycle. The children's golden age period is a period where the children's brain and intelligence develop rapidly. The limit of golden age period for children is from the age of 0-3 years old. Brain's development is an invisible development unlike the children's physical development. Therefore, the brain's

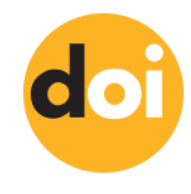


development of children is often neglected by parents. During the children's brain development in golden age period, the role of parents to support the children's development to optimize the process is very important.

In the golden age, the children will absorb anything that they see, hear, smell, feel, and touch from their surroundings. It should be a concern for parents. The children's subconscious is very active in the golden age period. Anything the children obtained from the environment will enter their subconscious easily. Parents need to pay attention to the stimuli from the child's environment. Parents should not say any words that have negative connotations to the children. Negative phrases such as "don't", "shouldn't be", "you are stupid" will enter the children's subconscious easily. These words will settle and, it will be reflected in their character later on. These words will turn the children into timid ones, they will lose their creativity and unable to develop themselves. Telling lies to children during this period also have a negative effect. They can imitate the behavior and it can become their character. Children need to be allowed to explore their surroundings. The more children learn from the environment, the more connections between nerves (synapses) in the children's brain are formed. The more connections between nerves (synapses) that are formed means that the children will likely be smarter.

Scientific research shows that the storage capacity of the human's right brain is 10,000 times that of the left brain. Various studies conducted by Professor Shichida from Japan show that the brain of a 3-year-old child has completed $60 \%$ of his brain development and has completed nearly $90 \%$ of his brain development before the age of 6 years. Parents should realize that after the child is 6 years old, his right brain development will start to decline. The period of children under 3 years old is the richest period in the development of the child's right brain. If we can do the right stimulation during this period, children will have a strong memory, creativity, and high imagination. One thing that can support the development of this golden age is through games that optimize the development of the child's right brain.

Therefore, an intelligence optimization in the golden age period by stimulating the right brain in Mojokrapak Village, Tembelang District, Jombang Regency

\section{METHODOLOGY}

The method used to perform intelligence optimization in the golden age period by stimulating the right brain in Mojokrapak Village, Tembelang District, Jombang Regency is community relation method through health education and training to mothers. So that mothers know, understand, and grow an attitude of awareness of the importance of the Golden Age Period or the golden age of growth as an effort to improve the quality of children's growth. The mothers are expected to know, understand, can apply the knowledge received in training in everyday life, and a transfer of knowledge from the mothers to their children is also expected to happen.

In performing community research, the following steps are needed to create a proposal of community research then submit the proposal that has received an approval from the Head of the Jombang District Government Stikes to LPPM. Then, send a notification letter of community service to the Public Health Office, PKM Tembelang, and the residents of the village. We also, performing coordination with the village's Midwive to decide the place of the community research and a targeted number.

Cooperate with the head of the village to prepare the site for the community service is a must. Then, inviting the students to participate in preparing the facilities and infrastructure that will be used for the community service. Preparing the attendance list of the targeted audience. Giving socialization and training to the target. Performing a socialization and training to the audience. Giving feedback to the targeted audience. Giving chance for the audience to ask 
questions. Conveying the conclusion. Closing the socialization event. And then, giving leaflet and mementos to the targeted audience.

\section{HASIL DAN PEMBAHASAN}

The activity was held at Integrated Healthcare Center (Posyandu), Mojokrapak Village, Tembelang District, Jombang Regency on September 20, 2018, which was attended by 28 mothers and toddlers. The implementation of the community service begins with the counseling on Optimizing Intelligence in the Golden Age by Stimulating the Right Brain.

The target of community service activities is all mothers and toddlers who attend the Integrated Healthcare Center (Posyandu), totaling \pm 28 mothers and toddlers. The result are:

1. Community service activities run smoothly

2. The material was presented by Rini Hayu Lestari, SST, M.Kes and Mudhawaroh, SST., M. Kes as the speaker and organizer on Optimizing Intelligence in the Golden Age with Right Brain Stimulation

3. The activity lasted for 2 hours

4. 28 outreach participants consist of mothers and toddlers

5. Participants are quite enthusiastic and communicative with the speaker

6. Activities other than counseling were also carried out with discussion and question and answer activities to the participants.

7. The questions asked by extension participants varied

8. Mothers understand the benefits and importance of optimizing children's brain development.

Stimulation plays an important role in the development of children during the golden age.

Stimulation is an effective way to develop children's abilities. It can be done directly by parents or by creating a safe environment so that children will feel comfortable exploring their surroundings. With stimulation, it is expected that the child's ability, both gross motoric, fine motoric, language, and social personality will develop well. The development of this ability will be an important factor in the development of children's intelligence in the future. There are four kinds of stimulation to give to children, they are stimulation of touch, balance, hearing, and visual.

Parents should realize that after the children reach the age of 6 , their right brain development will start to decline. The period of children under 3 years is the richest in the children's right brain development. If we can do the appropriate stimulation during this period, children will have a strong memory, creativity, and high imagination. One thing that can support the development of this golden age is through games that optimize the development of the child's right brain.

The role of parents is critical during the golden period of children. If parents know the importance of this golden period for optimal children's brain development, they will give the best for their children. It is because having smart children is the dream of every parent, especially children who can be the pride for the country and the nation.

\section{CONCLUSION}

This community service gives many benefits for the mothers of toddlers and their family (fathers, grandmothers, grandfathers), the implementation of the benefits is in the improvement of the knowledge. After the improvement of the knowledge is implemented, an awareness of the importance of Golden Age Period or the gold period of the children's growth is expected. 
During this golden age period, children should not be exposed to too much cognitive things. Parents should not give the children excessive math lessons, language knowledge (for example, forcing children to learn English), and others. Those lessons are for left-brain development instead of right-brain development. In this golden age period, the rapid development occurred is for the right brain's function. Left brain development usually occurs after the children reached the age of 3 or more. The stimulation performed should be focused on optimizing the development of the child's right brain to prepare for the next left brain development.

\section{BIBLIOGRAPHY}

Sudarti and Endang, K. (2015). Asuhan Kebidanan: Neonatus, bayi, dan anak balita. Jakarta: Medical Book.

Tando, N. M. (2016). Asuhan Kebidanan Neonatus, Bayi \& Anak Balita. Jakarta: EGC.

Ten Teachers. (2016). Asuhan Kebidanan pada Bayi yang Baru Lahir. Jakarta: Pustaka Pelajar. 